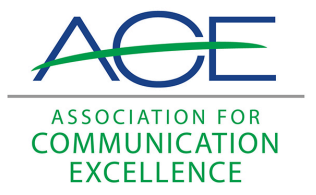

Journal of Applied Communications

\title{
Media Access as a Function of Source-Group Identity; Comic Books: an Effective Teaching Tool; Factors Affecting Response Rates to Mailed Questionnaires: A Quantitative Analysis of the Published Literature.
}

Larry Meiller

Lloyd R. Bostian

Follow this and additional works at: https://newprairiepress.org/jac

(c) (i) (-)

This work is licensed under a Creative Commons Attribution-Noncommercial-Share Alike 4.0 License.

\section{Recommended Citation}

Meiller, Larry and Bostian, Lloyd R. (1979) "Media Access as a Function of Source-Group Identity; Comic Books: an Effective Teaching Tool; Factors Affecting Response Rates to Mailed Questionnaires: A Quantitative Analysis of the Published Literature.," Journal of Applied Communications: Vol. 62: Iss. 2. https://doi.org/10.4148/1051-0834.1864

This Review is brought to you for free and open access by New Prairie Press. It has been accepted for inclusion in Journal of Applied Communications by an authorized administrator of New Prairie Press. For more information, please contact cads@k-state.edu. 


\title{
Media Access as a Function of Source-Group Identity; Comic Books: an Effective Teaching Tool; Factors Affecting Response Rates to Mailed Questionnaires: A Quantitative Analysis of the Published Literature.
}

\author{
Abstract \\ Reviews of "Media Access as a Function of Source-Group Identity," by David L. Schwantes and James B. \\ Lemert; "Comic Books: an Effective Teaching Tool," by Curtis Trent and Rachel Kinlaw; "Factors Affecting \\ Response Rates to Mailed Questionnaires: A Quantitative Analysis of the Published Literature," by Thomas \\ A. Heberlein and Robert Baumgartner.
}




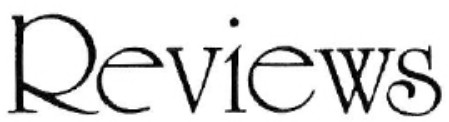

Reviews are prepared by Larry Meiller, Lloyd R. Bostian and others in the Department of Agricultural Journalism, University of Wisconsin-Madison.

"Media Access as a Function of Source-Group Identity." David L. Schwantes and James B. Lemert. Journalism Quarterly, winter, 1978. Vol. 55 No. 4 pp. 772-775.

Does a source representing an organized group have greater access to news coverage than a source without group idenity? This study tested whether unaffiliated individuals are as likely to be quoted directly, have statements attributed to them by name, and have background information on them presented, as compared with persons representing groups.

The method was a labortory experiment in which reporters (journalism reporting students) decided whether they would use material fitting these situations. Results show reporting students devoted more space to group sources than to unaffiliated ones. Also, within stories using both group and unaffilited sources, they usually quoted the group sources first. When forced to choose one type, students rejected the unaffiliated sources.

However, no difference was found in using direct quotes, from the two types of sources. And more background information was presented for the unaffiliated sources than for groups.

Since ACE sources are almost always affiliated, we probably ought to make the most of the group source. So when releasing news from a university or agency, clearly stating either as the source may be more beneficial than stressing the individual expert. For example, editors may evauluate a story higher if it indicates that the University of has advice rather than simply that John Smith, specialist, has advice. 
“Comic Books: an Efffective Teaching Tool," Curtis Trent and Rachel Kinlaw, Journal of Extension, January/February, 1979, pp 18-23.

One of the problems facing ACE members lies in communicating with disadvantaged people. This group receives few newspapers, belongs to few organizations, seldom attends educational meetings, reads little and generally has a lower level of literacy. Their only commonly used communication medium is commercial television. This article reports on a project conducted in North Carolina. In it the authors combined some aspects of commercial television with comic books to reach Expanded Food and Nutrition Education Program (EFNEP) homemakers.

The authors note that while most assume only children read comics, some show comic readership is highest for those between the ages of 30 and 39. The educationally disadvantaged are not avid readers of comics-the highest readership is among college graduates. Apparently the stigma attached to being "caught" reading comics is great among the disadvantaged.

The authors found that 95 percent of the EFNEP homemakers in North Carolina had one or more working television sets and that the type of program most frequently watched was the daytime serial. They obtained written permission from the TV network, sponsor, producer and cast of "The Edge of Night" to use that show's form and characters in the project.

First, six basic concepts on foods and nutrition were identified. Then these concepts incorporated into a set of comic books that presented a continuing, emotion-packed story. The story began in the first book and was completed in the sixth. The books were sent over a six-week period to a random sample of EFNEP homemakers. A pretest and posttest of knowledge and practices were given through personal interviews by EFNEP aides.

The results of the study showed that 94 percent of the homemakers who received the comic books read them and gained in both the knowledge and practices related to the six concepts. Attitudes toward the comic book as an educational medium were generally positive. Those who preferred daytime serials, read funny papers and blacks expressed slightly more positive attitudes than other groups. 
Meiller and Bostian: M edia Access as a Function of Source-Group Identity; Comic Books:

The authors cautioned against indiscriminate use of comics in teaching the disadvantaged adult. For example, they questioned whether EFNEP homemakers would actually read abstract comic books. Comic books without characters and format that the homemakers can identify with may inhibit learning and change-especially if they appear childish or immature.

"Factors Affecting Response Rates to Mailed Questionnaires: A Quantitative Analysis of the Published Literature.' Thomas A. Heberlein and Robert Baumgartner. American Sociological Review, Vol. 43 (August, 1978), pp. 447-462.

Research on mail questionnaire response rates generally has studied the effect of a single or limited number of factors on the response rate while attempting to hold all other factors constant. This study used a multivariate analysis of 71 factors from 98 methodological studies of mailed questionnaires to determine which factors alone and which factors in combination affect response rates.

The 71 factors affecting response rates fit into four broad categories: 1) General research characteristics, 2) Sampling and sample characteristics, 3) Questionnaire characteristics, and 4) Research procedures. For the 98 studies coded, there were 214 treatments of the independent variables. The unit of analysis was the treatment.

On the average, 48 percent of those who received one mailing of a questionnaire returned it. However, the range was from 20 percent to 80 percent. One follow-up mailing netted an additional return of 20 percent of the initial sample. A second and third follow-up yielded 12 percent and 10 percent respectively. However, the substantial variability in the effectiveness of follow-ups makes generalizations difficult.

Salience was a good predictor of response rate. Respondents are more apt to return questionnaires on topics of importance to them. The response for non-salient topics averaged 42 percent as compared with 77 percent for salient topics. Together salience and the number of contacts accounted for 50.5 percent of the variance in response rate.

Surveys of the general population were less likely to be returned than surveys of special subgroups. This was true even when controlling for salience.

Published by New Prairie Press, 2017 
Government sponsored research got higher responses independent of contacts and salience than other research sponsors.

In spite of the great variation in questionnaire length, no significant correlation was found between length and overall response although the response rate tended to be slightly lower for longer questionnaires. Quite possibly length affects the perceived importance of the questionnaire. Tossing out a one-page questionnaire may be relatively easy to do, but discarding 30 pages of questions may be seen as depriving the researcher of a good deal of information.

The authors recommended that in addition to lowering respondent costs (time and money), the researcher should increase the motivation of the respondents. Apparently the most effective way to do this is to increase the perceived importance of the study and the individual's response to it. Each individual contact further serves to convince respondents of the importance of their input. Contacts that show some special attention or greater expense and effort by the researcher (certified mail, telephone calls, personal contacts) also seem to increase this sense of importance. 